\title{
The Institute for Fiscal Studies Report: English Council Funding: What's Happened and What's Next?
}

\author{
COLIN COPUS AND ALISTAIR JONES
}

\begin{abstract}
The article reviews the recent Institute for Fiscal Studies (IfFS) report, English Council Funding: What's Happened and What's Next. The article provides an overview of the main themes and findings of the report which examines the consequences of a sustained period of austerity for English local government and the impact of austerity on certain key council services. The article explores what the report has to say about the way councils have responded to reductions in government funding and the strategies they have developed to protect certain frontline services. The article reviews the suggestions made in the IfFS report for changing English local government funding and finds that they reflect a form of centralist thinking which lacks a radical edge when it comes to reform.
\end{abstract}

Keywords: local government finance, local government, centralism, localism, spending review

\section{Introduction}

THE INSTITUTE for Fiscal Studies' recent report on English council funding has reignited the smouldering debate about what to do to provide local government with a sustainable and reliable funding regime. ${ }^{1}$ The detailed, well researched and clearly articulated report adds to the growing pressure on the centre to recognise fully the impact of long-term austerity on public services, community well-being and economic growth in the long term. Yet, it does take a centralist view of the financial ills facing local government and suggests top-down solutions with many of the arguments reflecting previous similar approaches. It is, however, a timely addition to the debate about council funding in England, which itself is currently the subject of an inquiry by the Housing, Communities and Local Government Committee of the House of Commons. The report is also set against the backdrop of the Fair Funding Review of public spending. It will also add weight to the long running campaign of the Local Government Association (LGA) to convince the government of the severe effects of spending reductions. Indeed, the report stresses the parlous situation that has confronted local government since 2009-10, when it has faced a 21 per cent spending reduction in real terms and now faces an $£ 8$ billion spending gap by 2025 . The report also shows that reductions have varied across councils, but that the tendency is to protect, as far as possible, adult and children's social care.

The next section of this paper will explore what the report has to say about the nature of the financial crises being experienced by English local government and how councils have responded. The third section will look at the next steps for local government finances and it is here that the report can be critiqued for not providing a radical assessment or set of next steps for financing English local government. The paper concludes by drawing together the main themes and lessons from what is an important and timely report.

\section{Reducing spending: how councils have responded}

The report points out that the 21 per cent spending reduction since 2009-10 across 
English local government has not been equally distributed and has been larger in worse-off areas than in more affluent places. Furthermore, and associated with that, reductions have also varied across services. The report states that

cuts have averaged $31 \%$ for the most deprived fifth of council areas, compared to $17 \%$ for the least deprived fifth of council areas. Spending per person in the most deprived areas has fallen from 1.52 times that in the least deprived areas on average in 2009-10 to 1.25 times in 2017-18. ${ }^{2}$

It is clear in the report's findings that councils have done what most would expect them to do in a period of sustained austerity, and that is to focus significant spending reductions, as far as they are able, on the discretionary services. In such a way, adult and children's services can be protected, to a degree, while planning, environmental services, central (administrative) services, highways and transport, culture and leisure and housing services have borne the brunt of spending reductions. But the report also points out that the protection of some areas of some services - noticeably those which are child-related-has masked cuts elsewhere. For example, children's service spending has gone up by 10 per cent, but Sure Start schemes (a programme targeted at parents and children under the age of four living in the most disadvantaged areas) have been cut by 60 per cent. The report doesn't refer to this as a 'false economy' but arguably it could be seen as such.

What the strategy of cutting back on discretionary services means is that because reductions have fallen on some of the higher-visibility areas - such as libraries - the result gives an impression of a locality in decline. While few would resent such a strategy, it does mean that more and more local spending is used for fewer and fewer citizens. Councils have also shown considerable sophistication in this approach by maintaining support, as far as possible, for the acute services such as those for children and housing, while reducing funding in the less acute aspects such as advisory services - thus ensuring the areas of greatest need continue to be met. The report, however, casts some doubt over the continued viability of this strategy - especially as demand continues to grow and centrally provided resources continue to shrink. Because of the reduction in central government support, local government will have to rely on council tax and 75 per cent of the business rate income for the bulk of their funding and, as the report points out, these two taxes are highly unlikely to be able to keep pace with demand. Indeed, the report makes the point, starkly, that if council tax increased 4.7 per cent every year, half of the money raised by the mid-2030s would need to be spent on adult social care-and that is without any increases or improvements in standards or the level of provision. That much would be needed just to stand still.

Another value of the report, which deserves repeating widely, is that the reliance on central funding by certain councils has not been fully reflected in the way in which spending reductions have been made and where they have had greatest impact. According to the report, even though the government reformulated its approach in 2016-17, the different tax basis and the varying needs of deprived and affluent areas has not been fully appreciated by central government. All of this data adds grist to the LGA mill in pressurising government to relax and reassess its financial approach to local government spending and in providing clarity and certainty about how local services will be paid for in the future.

The report urges caution over the government's flagship policy of Business Rate Retention (BRR) - the amount that local authorities retain from the business rates income generated in their area)-and increasing the retained element of the tax from 50 per cent to 75 per cent by 2020. The policy is aimed at both devolving what, after all, is a local tax (because it is raised from businesses locally) and providing incentives to local councils to take better control over their finances, thus increasing the money available to them. The report warns that such a policy could result in greater funding divergence between areas across England and between counties and district councils. The IFS notes a crucial aspect of the proposed policy in that it is combined with further planned cuts to grants from central to local government. This will 
enhance one of the problems highlighted in the report, that is, that those local authorities which have already been affected most by austerity measures will suffer again. The report is aware of the different funding pressures, service responsibilities and tax bases of county and district councils. Accordingly, it reflects the existing tensions between districts and counties - even within the LGA - as to who should gain from business rate retention, or who should lose least. However, in spite of this, it does not propose a radical shake-up of the funding system, meaning that the business rates and other monies available to English councils continue to be earmarked to fund essential services which are defined by central government. There would still not be enough funding available to spend on discretionary services, and hence what is in theory a 'local' tax is not seen as such by local authorities because the vast majority of it continues to be 'assigned revenue' under the control of central government.

Overall, the report emphasises the fragile position that English local government is in as a result of a sustained period of austerity, and it provides three very stark choices for the future:

(1) Removing the provision of some major responsibilities currently resting with local government;

(2) Retaining and increasing grant funding to local government over time;

(3) Providing councils with their own additional sources of revenue.

It is with relief that the report focusses next on the third point above, rather than dwelling the first and second points. But as we shall see in the next section, it is the want of a radical approach that somewhat undermines the valuable and relevant data that the report sets out.

\section{What happens next?}

The main weakness in the report is that despite the full and clear evidence it presents and discusses, it ducks the main logical question that it poses itself: 'So are we willing to accept greater differences in services between different areas in exchange for greater local control? Or should redistribution, ring-fenced funding and common standards be a central feature of the funding system ? $^{3}$

While there is some positive and favourable discussion of the old faithful-a local income tax-the report dismisses all too briefly a range of other taxation powers on the grounds that they raise too little funding (a tourist tax, for example) or are difficult to apportion between central and local government (such as corporate profits, stamp duty or VAT). Local income tax is seen as the most 'sensible option for devolution of significant new revenue-raising powers', but that suggestion is set very firmly in a centralist context and reflects a view that councils require one main source of tax income. ${ }^{4}$ Capping such a tax would be necessary to prevent competition between councils and inequality in terms of ability to raise revenue. One of the points of devolved financial powers - such as raising tax-is to allow local authorities to make their own choices about taxing and spending and to be held accountable for these through local elections. The report reflects highly centralised thinking about equalisation, retribution and a role for government in overseeing or apportioning a local tax centrally.

Indeed, the main weakness of the report is that it doesn't ask how so many other countries manage to make tourist taxes or local sales taxes or apportionment between central and local government work effectively. It is the dismissal of tourist taxes, for example, that indicates that the assumptions behind the report are wedded too greatly to the existing system and its operation. First, in dismissing tourist taxes, the report states that it 'would raise little more than $£ 0.4$ billion across England' (although few councils would turn down a share of such a sum). ${ }^{5}$ Second, and more importantly, the assumption appears to be that all councils would use such a tax, but that only a few areas would benefit. This does not acknowledge that those benefitting would require less government support, thus freeing up central resources for use elsewhere. Thirdly, the calculation is based on $£ 1$ per person per night, which is an extremely narrow approach to tourist taxes. Councils should be free to set their own rate for such a tax, which could be supplemented by, for example, a 1 per cent levy on restaurant bills, shopping bills, or 
entrance to leisure and tourist attractions, all of which are feasible and exist across Europe. Local citizens, of course, could be refunded through a rebate system, or reductions in other taxes. What the report seems to ignore is that councils could choose from a basket of taxes and that both rates and the choice of other taxes should vary across the country.

The report, while an extremely valuable review of where we are now, is far less helpful in assessing where we should go next and is locked in the current system and its concerns, rather than seeking radical alternatives. There is little willingness to see local government as just that - the government of the localities-rather than as a mechanism through which central government can operate and should oversee. The assumptions underpinning the report that the centre should decide are familiar ones which affect not only finance, but the constitutional status of local government, its relationship to other parts of the public and private sector and to central government, and its purpose in our governing system. While we focus on finance, as topical and vital as it is, we should not ignore the much broader public debate needed to assess the reforms required to enable local government to govern locally.

The report provides a form of response by suggesting that a public debate is needed on the question of centralist or localist responses and approaches to the financial problems facing English local government. But one thing local government is not short of is commissions, reports, inquires, investigations and debates on its future and on its financing. These range from the 1976 Layfield report right up to the IfFS's latest contribution. ${ }^{6}$ What is needed is less of a public debate and more action, and that action must be based on the principle of extending the tax raising powers of English local government from one of the most restrictive across Europe to one of the most expansive and flexible. A quick review of taxation regimes for local government overseas provides a starting point for thinking through change to enhance local government financial sustainability and to provide the necessary flexibility to withstand prolonged periods of centrally imposed austerity. While other countries may well have a prime source of local taxation, they often augment this with other revenue sources. Councils could secure financial freedom by generating tax income from an expanded basket of taxation powers from which each council would choose and set its own level. The list below provides examples used in other countries:

- Local income tax (Belgium, Canada, Denmark, Finland, Germany, Norway, Sweden, Italy, Sweden, Switzerland);

- Direct tax on business (Canada, Denmark, Finland, Hungary, Germany, Italy, Japan, Luxemburg, Portugal, US);

- Sales tax/consumption tax (Canada, Brazil, Germany, Hungary, Italy, Japan, Portugal, Spain, various US states);

- Tax on the self-employed (Germany);

- Entertainment tax (Croatia);

- Local property tax (Australia, Belgium, Canada, France, Japan, New Zealand, Spain, Switzerland, the Netherlands, US);

- Tax on land (Denmark);

- Tax on patents (transferred to councils in Bulgaria);

- Real estate tax (Poland, Brazil);

- Poll tax (Slovenia);

- Tourist tax (Belgium, Canada, Czech Republic, France, Germany, Hungary, Italy, Spain, Switzerland, the Netherlands). This type of tax is prevalent across Europe;

- Car tax (Spain, Croatia);

- Inheritance and gift tax (Croatia);

- General tax raising powers, for example, dog owners' tax, passport issuing, sewage tax, revenue from sale of brownfield land for development (Flanders, the Netherlands). Some of these taxes are shared between central and local government.

It is commonplace in reports on English local government finance to dismiss all but the most long-standing and often rehashed alternatives - which from Layfield on appear in the form of a local income tax-as too complicated, raising insufficient revenue, requiring central oversight and control, or being too radical. Nevertheless, the taxes in the list above work, and work well. Yet, debates about English local finance are wrapped in a set of centralist assumptions that cannot see the logic or desirability of a more radical and localist base to local government and its 
financing. Moreover, there is a strong reluctance to examine with any real purpose those local taxes that are commonplace overseas and to consider how they should fit in to the English local government context.

The lessons to draw for English local government from the taxes that rest with local government overseas, and which the IfFS report fails to do, is that it is far from necessary to constrain local government to just one main source of local taxation. Moreover, there is no need for all councils to rely on the same sources of local taxation. Instead, they could employ varying rates of varying taxes depending on their own local circumstances, which would be decided by-and indeed changed by-councillors elected in each locality. Such a system, however, would make central control and oversight far more difficult. Another public debate, as suggested by the IfFS, would lead to the same result as the other debates on the same subject: no action because it's too difficult. While the report throws serious light on the dangers of continuing along the same path as now, it is less helpful in setting out a way forward.

\section{Conclusion}

The IfFS report is a necessary and timely contribution to the debate about the future funding of English local government and poses the challenges ahead in stark and realistic terms. It offers no recommendations as such, but rightly states that opinions over the choices available for change can and do differ, with there being no right or wrong answer. The report states, however, that we cannot 'keep muddling through' and asks whether we are willing to raise extra revenue or else lower expectations about what local government can and cannot provide. It also posits the question as to whether we are prepared to tolerate different service levels across the country and allow councils to respond to local need and opinions, or should the centre take more control over local finance and decisions about local services? The localist-centralist tension is evident throughout the report.

The report leaves that localist-centralist question unanswered, but the issue of the unsustainability of the current system is made clear and the report provides ample evidence of that position. Yet, we cannot avoid the conclusion that the report has sat on the fence when it comes to solutions to the important issues it raises. Perhaps that is because it adopts an approach to the financing of local government that reflects the current centralist-controlled thinking about local government-where both the problem analysis and solutions fit with the current centralised system.

There is an understandable need and desire to address the inadequacies of the current regime for financing English local government, but the problem we have is that so much of the current debate is focussed on the minutiae of that system, on who would win or who would lose through tinkering with that system, or on how it can be made fairer (however that might be defined) and through the processes of system-constrained thinking such as in the Fair Funding Review. Focussing on these details means that we lose sight of more radical, flexible and localist solutions that work elsewhere. The Institute for Fiscal Studies report is to be welcomed as a significant contribution to an ongoing debate- but we still need more radical thinking.

\section{Notes}

1 English Council Funding: What's Happened and What's Next, Institute for Fiscal Studies, London, 2019; https:/ / www.ifs.org.uk/publications / 14133 (accessed 5 July 2019).

2 Ibid., p. 5.

3 Ibid., p. 15.

4 Ibid., pp. 8-9.

5 Ibid., p. 8.

6 Layfield Committee, Report of the Committee of Enquiry into Local Government Finance, Cmnd 6453, London, HMSO, 1976. 